\title{
Ortaokul matematik derslerinde dinamik geometri yazılımı Geometer's Sketchpad kullanımı ile ilgili öğrenci görüşleri
}

\author{
Kevser ERDENER ${ }^{*}$, Hülya GÜR \\ Balıkesir Üniversitesi, Necatibey Eğitim Fakültesi, Matematik ve Fen Bilimleri Eğitimi Bölümü, \\ Matematik Ĕgitimi Anabilim Dalı \\ Geliş Tarihi (Recived Date): 10.08 .2018 \\ Kabul Tarihi (Accepted Date): 11.10.2018
}

\section{Özet}

Teknolojinin matematik derslerinde kullanılmaya başlanmasıyla birlikte dinamik geometri yazılımlarının matematik eğitimindeki önemi artmıştır. Bu çalışmada dinamik geometri yazllımlarından Geometr's Sketchpad'in (GSP) matematik derslerinde kullanılmasının öğrenciler üzerinde etkisi araştırılmıştır. Çalışma Bursa'nın Mustafakemalpaşa ilçesinde bir ortaokulda yürütülmüştür. Geometer's Sketchpad yazılımı ile tasarlanan etkinlikler, açık uçlu sorulardan oluşan çalışma yaprakları ile desteklenerek ortaokul 7. sınıf öğrencilerine uygulanmıştır. Etkinlik uygulandıktan sonra bu öğrencilerden 8 tanesi ile görüşme gerçekleştirilmiş ve görüşmede 7 tane açık uçlu sorudan oluşan görüşme formu kullanılmıştır. Öğrencilere matematik derslerinde Geometer's Sketchpad yazllımı kullanımı ile ilgili görüşleri sorulmuştur. Öğrencilerin görüşlerinden elde edilen nitel verilerin analizinde içerik analizi yöntemi kullanılmıştır. Çalışma bulgularına göre Geometr's Sketchpad kullanımının öğrencilerin matematik dersine yönelik görüşlerini olumlu yönde değiştirdiği sonucuna ulaşılmıştır. Ayrıca çalışma sonuçlarına gore matematik dersinde Geometer's Sketchpad yazılımının kullanımı ögrencilerin geometrik kavramları ögrenmesini kolaylaştırmış ve öğrenilen kavramların kalıcılı̆̆ artırmıştır.

Anahtar kelimeler: Dinamik geometri yazılımı, Geometer's Sketchpad, ögrenci görüşleri.

\footnotetext{
* Kevser ERDENER, kevserbozbiyik@hotmail.com, http://orcid.org/0000-0002-3829-1240

Hülya GÜR, hgur@balikesir.edu.tr, http://orcid.org/0000-0001-8479-8811
} 


\title{
Students' views towards using the dynamic software Geometer's Sketchpad in middle school mathematics classrooms
}

\begin{abstract}
The importance of dynamic geometry software has been increased in mathematics education by means of using technology in mathematics classes. This study was conducted in a middle school in Mustafakemalpasa in Bursa. The effects of using the dynamic software Geometer's Sketchpad (GSP) on middle school students in mathematics classes was searched in this study. The worksheets including the open ended questions, filling in the blank parts and the activities which were designed by GSP software were used during the lessons. At the end of the lessons, the interview which includes seven open ended questions was carried out with eight middle school students. The students were asked their opinions about using GSP in their mathematics classes. Content analyses method was used to analyze the qualitative data which was obtained from interviews. The result of the analysis indicates that at the end of the lessons students' views about learning mathematics are changed positively by virtue of using GSP. Furthermore using GSP in mathematics classes facilitates the students' learning of geometry concepts and improves the retention of learned concepts.
\end{abstract}

Keywords: Dynamic geometry software, Geometer's Sketchpad, students’views.

\section{Giriş}

Bilişim teknolojilerinin matematik eğitiminde kullanımı gün geçtikçe yaygınlaşmaktadır. Teknolojinin sınıflara girmesi aslında çok yeni bir gelişme değildir. 1980 li yılların başından bu yana teknoloji matematik eğitiminde kullanılmaktadır. İlk olarak sadece işlem yapan hesap makineleri daha sonra grafik hesap makineleri matematik ögretiminde kullanılmıştır. Bilişim teknolojilerindeki gelişmelerin matematik eğitimine diğer bir katkısı da dinamik geometri yazılımları ve bilgisayar cebiri sistemleri gibi bilgisayar araçları olmuştur. Matematik sınıflarında kullanılan bilgisayar araçları doğru kullanıldığı zaman istenilen hedeflere ulaşılmış olur. Bilgisayar araçlarının doğru kullanılmasından kasıt öğrencilerin üst düzey matematik becerilerini geliştirecek şekilde kullanılmasıdır. Diğer bir ifadeyle bilgisayar araçları öğrencinin varsayımda bulunmasını, test etmesini, genelleme yapmasını sağlayan bir araç olarak kullanılmalıdır [1]. Bilgi ve iletişim teknolojilerinin sınıflarda verimli bir şekilde kullanılması etkili bir entegrasyon gerektirir. Etkili entegrasyon, teknolojiden öğrenmeyi değil, teknoloji ile öğrenmeyi gerektirir [2]. Diğer bir ifade ile etkili entegrasyon teknolojinin bir sunum aracı gibi veya ders kitabı gibi bir araç olarak kullanılması değil öğrenci merkezli bir sınıf ortamında kullanılan yöntem ve teknikle bütünleşmesi, öğrencinin bilgiyi yapılandırmasında etkin rol oynaması demektir.

Geleneksel sınıf ortamlarında görselliğe dayanan bir ders olan geometrinin görsellikten uzak etkinliklerle öğretilmeye çalışılmaktadır. Tahtada anlatılanların öğrencilerden kalem, 
kağıt ve cetvel kullanılarak defterlerine aktarmaları istenmekte ve sınırlı sayıdaki çizimlerle öğrencilerden uzamsal görselleştirme düşüncelerinin geliştirilmesi beklenmektedir [3]. Geleneksel sınıf ortamlarının tersine Geometer's Sketchpad ile oluşturulan dinamik geometri ortamlarında öğrenciler geometrik şekilleri hareket ettirerek, biçimlerini değiştirerek ve ölçümler yaparak şekillerin özelliklerini keşfedebilirler ve ilişkilendirebilirler böylece öğrenci merkezli ortamlar sağlanmış olur [4].

Dinamik geometri yazılımlarının derslerde kullanılması ile ilgili öğrenci ve öğretmen görüşlerini araştıran çalışmalar yapılmıştır. Genç ve Öksüz (2015), GeoGebra kullanımı ile öğretimin başarıya ve kalıcılığa etkisini ortaya koymayı amaçlayan bir deneysel çalışma yapmışlardır [5]. Çalışma sonucuna göre dinamik geometri yazılımı kullanımının, öğrencilerin başarılarına olumlu etki ettiği ve başarılarını arttırmada etkili olduğu anlaşılmıştır. Ayrıca öğrencilerin kavramları anlama ve uygulama anlamında kalıcı bir öğrenme gerçekleştirdikleri görülmüştür. Diğer bir çalışmada dinamik geometri yazılımları ile çokgenler konusunda hazırlanan etkinliklerin öğrenci performansı ve öğretmen görüşlerine yansımasını araştıran Delice ve Karaaslan (2015) Geogebra ve Geometer's Sketchpad yazılımları ile hazırlanan etkinliklerin öğrencilerin performansını olumlu yönde etkilediğini, öğrencilerin konuları daha iyi öğrendiklerini belirtmektedir. Ayrıca bu tür etkinlikler sayesinde öğrencilerin dersi eğlenceli bulduklarını ve derse karşı ilgilerinin arttığını belirlemişlerdir [6].

Dinamik geometri yazılımları etkili kullanıldığı zaman öğrencilerin deneyimlerini destekler ve öğrencileri araştırma yolu ile öğrenmeye teşvik eder [1]. Yapılan araştırmalar gösteriyor ki bilgisayar destekli sınıf ortamı öğrencilerin geometriye karşı tutumlarını olumlu yönde değiştirmelerini sağlmakta ve eğitim-öğretimin verimliliğini ve kalıcılığını arttırmaktadır [7]. Teknoloji araçlarının matematik sınıflarında kullanılması sadece öğrencilerin olumlu tutum geliştirmelerini sağlamakla kalmaz, aynı zamanda öğretmenlerin iş doyumunu sağlar bununla birlikte öğretmen ve teknolojinin birbirini bütünlemesi, eğitim öğretimde kalitenin artmasina yardımcı olur [8].

Dinamik geometri yazılımlarının etkili kullanımının yanı sıra programın özellikleri de geometrinin etkili öğretimini ve öğrenciler tarafından anlamlı olarak öğrenilmesini etkilemektedir. GSP kullanırken öğrenciler komutlara kolayca ulaşılabilir, nesnelere dokunur, sürükler ya da boşluğa tıklayarak kolayca aktif edilebilir, komutların doğruluğu ya da yanlışlığı anında ekrandan anlaşılabilir, öğrenciler kendileri oluşturdukları yapıları kaydederek yeni bir araç oluşturabilir ve bu aracı daha sonra kullanabilirler [9]. Ayrıca GSP akıllı tahta ile uyumlu çalıştığından öğrencilerin derse interaktif katılımını kolaylaştırmaktadır. Yapılan çalışmalarda GSP kullanan öğrenciler şekiller ve özellikleri arasındaki ilişkiyi keşfettiklerini ve daha iyi anladıklarını, programın görsel özelliklerinin onları daha iyi motive ettiğini ifade etmişlerdir. Ayrıca geometrik şekilleri hareket ettirmek, sürüklemek öğrencilere ilgi çekici gelmiş ve bütün bunları yaparken daha yaratıcı olmuşlardır [10]. 


\section{1 Çalışmanın amacı}

Alan yazında bu zamana kadar yapılan araştırmalarda matematik sınıflarında teknoloji kullanımı ile ilgili öğrenci görüşleri araştırılmış fakat teknoloji ürünleri kapsamında GSP'ye sınırlı olarak yer verilmiştir. Yapılan çalışma ile bu eksikliğin giderilmesi amaçlanmaktadır.

Matematik sınıflarında Geometer's Sketchpad kullanımının yaygınlaşması, öğrencilerin dinamik geometri ortamında, bilgisayar kullanarak geometri öğrenme ile ilgili görüşlerine ve tepkilerine bağlıdır. Bu çalışmanın amacı da öğrencilerin bir dinamik geometri yazılımı olan GSP ile tasarlanmış etkinlikleri uygulayarak geometri öğrenme ile ilgili görüşlerini almak ve bu görüşlere göre GSP nin sınıflarda kullanımının gerekliliği hakkında fikir elde etmektir. Bu amaçla aşağıdaki sorulara yanıt aranmıştır.

1. Öğrencilerin GSP'in matematik derslerinde kullanımı hakkındaki görüşleri nelerdir?

2. Matematik derslerinde GSP kullanımı öğrencilerin derse olan ilgilerini nasıl etkilemiştir?

3. Matematik derslerinde GSP kullanımı öğrencilerin geometrik kavramları öğrenimini nasıl etkilemiştir?

\section{Yöntem}

\section{1. Çalışma deseni}

Çalışmada özel durum çalışması yöntemi kullanılmıştır. Çünkü özel durum çalışmasında araştırmacı nasıl ve niçin sorularını temel alır ve kontrol edemediği bir olgu yada olayı derinlemesine inceleme olanağı bulur [11].

\subsection{Etkinlik tasarımı}

Çalışmaya başlamadan önce Geometer's Sketchpad ile hangi konuların öğrenileceğine karar verilmiştir. İlköğretim yedinci sınıf matematik öğretim programında yer alan "Koordinat Sistemi” konusunun ve ilköğretim altıncı sınıf öğretim programında yer alan "Üçgenler" konusunun kazanımları dikkate alınmasına karar verilmiştir. Çalışmanın ilk aşamasında etkinlikler tasarlanırken GSP yazılımı kullanılarak, dinamik özelliğe sahip etkinlikler hazırlanmış ve etkinliklerin uygun bir şekilde takip edilebilmesi için çalışma kağıtları geliştirilmiştir. Çalışma kağıtları, öğrencilerin bireysel çalışmalarını arkadaşlarıyla paylaşıp tartışabilmeleri ve çeşitli sonuçlara ulaşabilmeleri amacı ile grup çalışması yapmaları için tasarlanmıştır ve bu kağıtlarda öğrencilerin etkinlik boyunca takip edeceği yönergeler bulunmaktadır. Çalışma kağıtları hazırlanırken aynı okulda çalışan bir matematik öğretmeninin ve bir matematik eğitimi uzmanının görüşlerine başvurulmuştur.

\subsection{Etkinliklerin yapısı}

$\mathrm{Bu}$ çalışmada etkinlikler tasarlanırken gerçek yaşam problemlerinden matematiksel kavramlara ve sembollere ulaşma yani matematiğin gerçek yaşam durumları ile ilişkilendirilmesi ve yeniden keşfedilmesi esas alınmıştır. Etkinlikler tasarlanırken öncelikle iki boyutlu koordinat sisteminde verilen bir noktanın koordinatlarını bulma, şekil oluşturma, oluşturulan şeklin koordinatlarını bulma, eksenlere göre yansıma ve öteleme 
hareketlerinin özelliklerini keşfetmeye yönelik gerçek yaşam durumları oluşturulmuştur. Ayrıca öğrencilerin ikizkenar ve eşkenar üçgende açıortay, kenarortay ve yükseklik elemanlarının özelliklerini keşfetmesi için ve paralelkenar ile dikdörtgenin alanından faydalanarak üçgenin alanını hesaplayabilmeleri için dinamik bilgisayar ortamında gerçek yaşam problemi sunulmuştur. Sonra çalışma kağıtlarındaki sorularla etkinlikleri sürdürmeleri amaçlanmıştır. Etkinliğin sonunda istenen geometrik kurallara ve genellemelere ulaşmaları amaçlanmıştır.

\subsection{Etkinlik uygulama öncesi hazırlık}

Etkinlik uygulamasına geçilmeden önce uygulamanın yapılacağı fiziki ortam çalışmaya uygun hale getirilmiştir. Çalışmanın yapılacapı okulda bilgisayar laboratuarındaki 1 ana bilgisayar ve 8 adet masaüstü bilgisayar kullanılmıştır. Bu bilgisayarlara Geometer's Sketchpad dinamik geometri yazılımı yüklenmiştir. Her öğrenci bir bilgisayarı kullanacak şekilde oturma düzeni oluşturulmuştur. Öğretmenin ana bilgisayarda gösterdiği etkinlikleri projeksiyon yardımıyla öğrencilerin takip etmesi sağlanmıştır.

Fiziki ortamın hazırlanmasından sonra öğrencilerin Geometer's Sketchpad yazılımını tanıması ve programın araçlarının özelliklerini öğrenmeleri açısından iki ders saati süresince öğrencilere eğitim verilmiştir. Bu eğitim süresince öğrencilere menülerin kullanımı açıklanmış ve öğrencilere nokta, şekil çizimi, oluşturulan şekillerin açı ve uzunluklarının ölçümü, metin kutusu ekleme, tablo oluşturma, koordinat sistemi oluşturma, ve araç oluşturma uygulamaları yaptırılmıştır.

\section{5. Çalışma grubu}

Çalışmanın örneklemi ölçüt örnekleme yöntemi ile seçilmiştir. Çalışma grubu Bursa ili Mustafakemalpaşa ilçesindeki bir ortaokulun yedinci sınıf öğrencileri içerisinden seçilen iki erkek ve altı kız toplamda sekiz öğrenciden oluşturmaktadır. Öğrenciler seçilirken farklı matematik başarısına sahip öğrenciler olmalarına dikkat edilmiştir. Sınıflardaki öğrenciler matematik başarılarına göre sıralanmış ve öğrenciler kötü, orta. İyi ve çok iyi olmak üzere dört başarı grubuna ayrılmıştır. Her gruptan ikişer öğrenci seçilmiş̧ir.

\subsection{Etkinliğin uygulanmast}

Öğrencilerden birinci derste GSP ekranında koordinat düzlemi olușturmaları istenmiștir. Bu derste ilköğretim yedinci sınıf matematik öğretim programındaki koordinat sistemi ile ilgili kazanımlara yönelik etkinlikler uygulanmıştır. İkinci derste ise öğrenciler altıncı sınıftaki üçgenler konusu ile ilgili kazanımlara yönelik etkinlikleri uygulamışlardır. Öğrenciler bireysel olarak başladıkları etkinliklerde oluşturdukları yapıları ve buldukları sonuçları yanındaki arkadaşı ile tartışmıştır. Tablo 1'de koordinat düzlemi ve üçgenler ile ilgili kazanımlar ve ders saatlerinin planlanması öğrencilerle yapılan uygulamanın içeriği olarak verilmiştir. 
Tablo 1. Öğrencilerle yapılan uygulamanın içeriği.

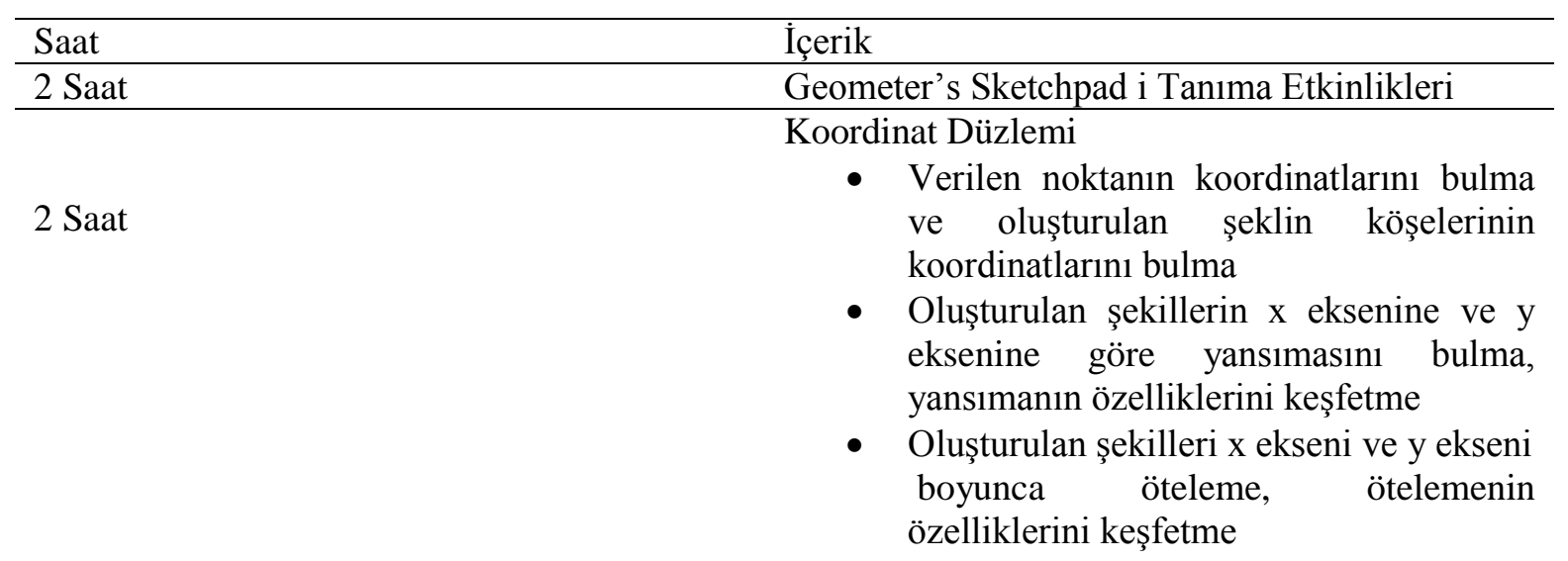

Tablo 1. (Devam).

- Ötelenen ve oluşturulan şekillerin yansıma ve öteleme sonucu boyutlarının değişmediğini keşfetme

2 Saat

Üçgenler

- İkizkenar üçgende ve eşkenar üçgende açıortay, kenarortay ve yükseklik özelliklerini keşfeder

- Dikdörtgenden paralelkenardan faydalanarak üçgenin alanını hesaplar.

\subsection{Verilerin toplanmast}

Çalışmada bireylerin geometri dersinde Geometer's Sketchpad dinamik geometri yazılımı kullanımı hakkındaki duygu ve düşüncelerini ortaya çıkarmak amacıyla yarı yapılandırılmış görüşme yöntemi kullanılmıştır. Görüşmeler her öğrenciyle bireysel olarak yapılmış ve görüşme formu kullanılmıştır. Bu sayede görüşme esnasında esnek bir yapı sağlanarak öğrencilerin fikirlerini rahatça ifade edebilmeleri amaçlanmıştır. Görüşme formunun kullanılmasının diğer bir sebebi ise görüşmeyi yapan kişinin soruların yapısını ve sırasını değiştirebilmesi ve ek sorular sorabilmesine imkan vermesidir. Görüşme soruları daha önce bu konuyla ilgili yapılan araştırmalarda sorulan görüş̧e soruları göz önüne alınarak düzenlenmiştir $[1,10,7,12]$. Düzenlenen sorular uzman görüşleri alınarak yedi açık uçlu soru şeklinde görüşme formunda yer almıştır. Tavşancıl ve Aslan'a (2001) göre nitel araştırmalarda içerik analizinin güvenirliği özellikle kodlama işlemine bağlıdır [13]. Kategorilerin taşıması gereken en önemli özelliklerden biri aynı dökümanı, aynı amaç doğrultusunda kullanan başka bir araştırmacının da büyük ölçüde benzer sonuçlara ulaşabileceği açıklıkta olmasıdır. Başka bir ifade ile görüşme formunda verilen cevapların kategorilenmesi araştırmacıdan araştırmacıya değişmemesi gerekir. $\mathrm{Bu}$ nedenle araştırmadaki görüşme sorularına verilen cevaplar bir uzman tarafindan kategorize edilmiştir. Araştırmacının ve uzmanın verilen cevapları benzer kategorilere kodladığı görülmüştür bu şekilde kodlama güvenirliğinin sağlandığı belirlenmiştir. Bassey’ e (1999) 
göre görüşülen kişinin ne söylediği ile ne söylemek istediği arasında farklılık olabilir bu yüzden görüşmede kaydedilen verilerin görüşülen kişiye gösterilmesi ile cevapların doğruluğu teyit edilmiş olur [14]. Bu durumda görüşmede elde edilen verilerin doğruluğu ve geçerliliği test edilmiş olur. Bu çalışmadaki görüşme sorularının geçerliliğini saptamak için kaydedilen cevaplar öğrencilere gösterilerek gerçekte söylemek istedikleri ile farklılık olmadığı belirlenmiştir. Görüşme soruları çalışmanın sonunda EK-1 bölümünde verilmiştir.

\subsection{Verilerin analizi}

Çalışmanın amacı öğrencilerin dinamik geometri yazılımı olan Geometer's Sketchpad kullanılarak geometri öğrenme ile ilgili görüşlerinin belirlenmesidir. Bu amaçla görüşme sonuçlarından elde edilen nitel verilerin analizinde içerik analizi yöntemi kullanılmıştır. Çünkü içerik analizinde temel amaç, elde edilen verileri açılayabilecek kavramlara ve ilişkilere ulaşmaktır [11]. Öğrencilerin görüşme sorularına verdikleri cevaplar kavramlaştırılarak ve aralarındaki ilişki incelenerek kodlanmış daha sonra bu kodlar araştırmanın alt amaçları doğrultusunda belirli bir tema altında sınıflandırılmış̧ır. Yıldırım ve Şimşek'e (2011) göre içerik analizinde üç tür kodlama vardır: 1. Daha önceden belirlenmiş kavramlara göre yapılan kodlama; 2. Verilerden çıkarılan kavramlara göre yapılan kodlama; 3. Genel bir çerçeve içinde yapılan kodlama [11]. Bu çalışmada verilerden çıkan kavramlara göre yapılan kodlama kullanılmıştır çünkü çalışmada daha önceden belirlenen kodlar bulunmamaktadır. Temalar, belirlenen benzer kodların belirli kategoriler altında toplanmasıyla elde edilir [15]. Öğrencilerin görüşleri ortaya çıkan kodlara ve temalara göre düzenlenmiş ve düzenlenen bulgular yorumlanmıştır.

Yapılan kodlama çalışmasının güvenirliğini belirlemek için veri seti farklı bir kodlayıcı tarafından kodlanmış ve benzerlik oranı hesaplanmıştır. Yapılan nitel çalışmanın teyit edilebilirliğini gösteren benzerlik oranı Miles ve Huberman modelinde içsel tutarlılık olarak adlandırılmıştır. Bu oran aşağıdaki formülü kullanılarak hesaplanabilir.

$\Delta=\mathrm{C} \div(\mathrm{C}+\partial) \times 100$

Formülde, $\Delta$ : Güvenirlik katsayısını, C : Üzerinde görüş birliği sağlanan konu/terim sayısını, $\partial$ : Üzerinde görüş birliği bulunmayan konu/terim sayısını ifade etmektedir. İçsel tutarlılığı veren kodlama denetimine göre kodlayıcılar arası görüş birliğinin en az \%80 olması beklenmektedir [16]. Güvenirlik çalışmaları kapsamında öğrenci cevapları araştırmacı ile nitel araştırma konusunda bir uzman tarafından ayrı ayrı analiz edilmiş ve yapılan kodlama sonucunda araştırmacı 24 tane, ikinci kodlayıcı ise 25 tane kod bulmuştur. Bulunan kodlardan 20 tanesi benzerlik göstermekte iken kalan kodların farklı olduğu görülmüştür ve yapılan hesaplama sonucu uyuşma oranı \% 80 olarak hesaplanmıştır. $\mathrm{Bu}$ oran kodlamanın güvenilirliğini diğer bir ifade ile çalışmanın teyit edilebilirliğini göstermektedir.

\section{Bulgular}

$\mathrm{Bu}$ bölümde öğrencilerin görüşme sorularına verdikleri cevaplar kodlanmış ve bu kodlar uygun temalara göre düzenlenmiştir. Temalarda öğrencilerin cevaplarından alıntı cümlelere 
yer verilmiştir. Elde edilen temalara göre ayrıştırılan veriler frekans ve yüzde teknikleriyle çözümlenerek açıklanmıştır.

Tablo 2' de öğrencilerin görüşmede sorulan 'Daha önceki matematik derslerinde işlenen geometri konuları ve bu konuların işlenişi hakkında düşünceleriniz nelerdir?” sorusuna verdikleri cevaplar ve analiz sonuçları gösterilmiştir.

Tablo 2. Öğrencilerin daha önceki derslerdeki geometri konuları ve konuların işlenişleri ile ilgili görüşleri.

\begin{tabular}{lllll}
\hline & & Öğrenci Görüşleri & f & \% \\
\hline \multirow{3}{*}{$\begin{array}{c}\text { Derse } \\
\text { Karşı }\end{array}$} & Araç & İşlediğimiz derste gerekli araçlar yok. & 2 & 25 \\
\cline { 2 - 5 } Tutum & Kullanımı & Cetvel dişında hiç araç kullanmıyoruz. & 4 & 50 \\
\cline { 2 - 5 } & & $\begin{array}{l}\text { Öğretmen tahtaya çiziyor şekilleri biz } \\
\text { defterimize çiziyoruz. }\end{array}$ & 8 & 100 \\
& & & \\
\hline
\end{tabular}

Tablo 2. (Devam).

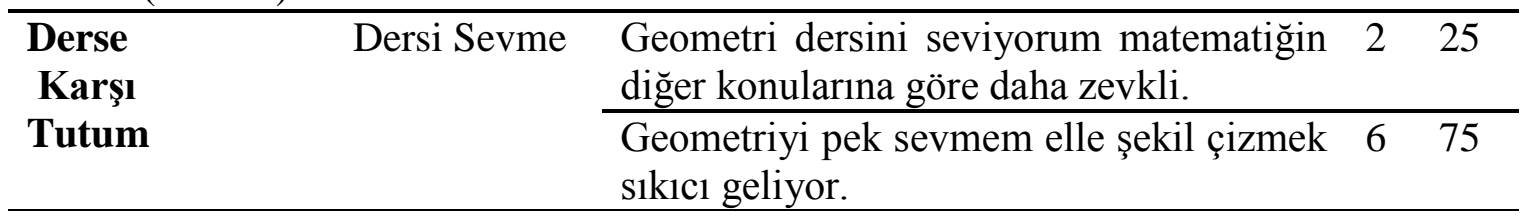

Tablo 2' ye göre öğrencilerin \%25' i işledikleri derste gerekli araçların sağlanamadığını, $\% 50$ si sadece cetvel kullandıklarını ve öğrencilerin hepsi ders işlerken öğretmenin tahtayı kullandığını belirtmişlerdir. Öğrencilerin \%25' i geometri konularını severken \%75' i elle şekil çizmeyi sevmediklerinden dolayı dersi sıkıcı bulmaktadır. Bu sonuçlara bakarak öğrencilerin aslında geometriyi sevdiklerini fakat derste materyal kullanmadıkları için dersi sıkıcı buldukları yorumu yapılabilir.

Tablo 3’ te öğrencilerin GSP ile ilgili olumlu düşüncelerine ve analiz sonuçlarına yer verilmiştir.

Tablo 3. Öğrencilerin GSP ile ilgili olumlu düşünceleri.

\begin{tabular}{|c|c|c|c|c|}
\hline & & Öğrenci Görüşleri & f & $\%$ \\
\hline \multirow[t]{4}{*}{ Öğrenme } & Akılda Kalıcı & $\begin{array}{l}\text { Öğrendiğimiz konular kafama daha iyi } \\
\text { giriyor, önceki çalışmada yaptıklarımı } \\
\text { unutmadım. }\end{array}$ & 6 & 75 \\
\hline & $\begin{array}{l}\text { Ayrıntılı } \\
\text { Açıklama }\end{array}$ & $\begin{array}{l}\text { Koordinat sistemini önceden de } \\
\text { görmüştüm ama burda daha ayrıntılı } \\
\text { herşey. }\end{array}$ & 3 & 37 \\
\hline & Keşfetme & $\begin{array}{l}\text { Üçgenlerin özelliklerini kendimiz bulduk, } \\
\text { öğretmen bize söylemedi. }\end{array}$ & 4 & 50 \\
\hline & $\begin{array}{l}\text { Etkin Zaman } \\
\text { Kullanımı }\end{array}$ & $\begin{array}{l}\text { Zamandan tasarruf sağliyor bence çünkü } \\
\text { koordinat sistemi hazır çizilmiş geliyor } \\
\text { ekrana. }\end{array}$ & 2 & 75 \\
\hline
\end{tabular}


Tablo 3. (Devamı).

\begin{tabular}{|c|c|c|c|}
\hline & & $\begin{array}{l}\text { Uzunluk,açı hesaplamak, üçgenin alanını } \\
\text { bulmak çok kolay onlarla vakit } \\
\text { kaybetmiyoruz. }\end{array}$ & 4 \\
\hline \multirow[t]{4}{*}{$\begin{array}{l}\text { Program } \\
\text { Özelliği }\end{array}$} & Görsellik & $\begin{array}{l}\text { Görsel açıdan çok güzel. Renkleri } \\
\text { seçebiliyoruz. }\end{array}$ & 62 \\
\hline & $\begin{array}{l}\text { Kolay ve } \\
\text { Doğru Şekil } \\
\text { Çizimi }\end{array}$ & $\begin{array}{l}\text { Şekilleri çizmek çok kolay, koordina } \\
\text { sistemi hazır onu çizmekle uğraşmıyorum. } \\
\text { Çizdiğim şekiller yamuk olmuyor düzgün } \\
\text { oluyor. }\end{array}$ & 75 \\
\hline & Eğlenceli & $\begin{array}{l}\text { Çizim yapmak çok eğlenceli. Şekilleri } \\
\text { uzatabiliyoruz, sürükleyebiliyoruz. }\end{array}$ & 87 \\
\hline & $\begin{array}{l}\text { Menü } \\
\text { Çeşitliliği }\end{array}$ & $\begin{array}{l}\text { Çok fazla özelliği var. Şekil } \\
\text { çizebiliyorum, hesap makinesi var } \\
\text { hesapladıklarımızı ekranda tutabiliyorum }\end{array}$ & 50 \\
\hline
\end{tabular}

Tablo 3’e göre öğrenme kategorisinde öğrencilerin $\% 75^{\prime}$ i GSP ile öğrendiklerinin daha akılda kalıcı olduğunu, \%37' si GSP de daha ayrıntılı öğrendiklerini, \%50' si bilgiyi keşfettiklerini ve \%75' i GSP nin etkin zaman kullanımı sağladığını belirtmişlerdir. Program özelliği kategorisinde öğrencilerin \% 62 si GSP programını görsel açıdan beğendiklerini, \%75 GSP ile şekillerin doğru ve kolay çizildiğini, \% 87’ i GSP ile ders işlemenin eğlenceli olduğunu, \%50' si de GSP de çok sayıda özellik olduğunu belirtmişlerdir. Bu sonuçlara göre öğrencilerin GSP programı ile geometri öğrenmeyi eğlenceli bulduklarını, görsel açıdan ve kullanılan özellikler bakımından programı beğendiklerini söyleyebiliriz. Öğrencilerin cevaplarına göre GSP ile yapılan etkinliklerle kalıcı öğrenme sağlanmış, öğrenciler keşfederek bilgiye ulaşmış ve zamanı etkin kullanmışlardır.

Tablo 4' te öğrenciler "GSP ile ilgili olumsuz düşünceleriniz nelerdir?” sorusuna cevap vermişlerdir.

Tablo 4. Öğrencilerin GSP ile ilgili olumsuz düşünceleri

\begin{tabular}{lllcc}
\hline & Öğrenci Görüşleri & f & \% \\
\hline $\begin{array}{l}\text { Program } \\
\text { Özelliği }\end{array}$ & Bilgisayara Bağl1lık & $\begin{array}{l}\text { Okulda sadece matematik } \\
\text { derslerinde çalışabiliriz evde } \\
\text { bilgisayarı olmayanlar ve } \\
\text { programı olmayanlar çalışmaz. }\end{array}$ & 1 & 12 \\
& & & \\
\cline { 2 - 5 } & Menüyü Kullanamama & $\begin{array}{l}\text { Çok fazla özelliği var çok karışık } \\
\text { geldi ilk başta. }\end{array}$ & 25 \\
\cline { 2 - 6 } & Araç Oluşturma & $\begin{array}{l}\text { Şekilleri oluşturmak çok zor } \\
\text { eşkenar üçgeni çizemedim uzun } \\
\text { süre. }\end{array}$ & 3 & 37 \\
& & & \\
\hline
\end{tabular}


Tablo 4. (Devami).

\begin{tabular}{|c|c|c|c|c|}
\hline \multirow[t]{3}{*}{ Çözüm } & Öğretmene sorma & $\begin{array}{l}\text { Anlayamadiğım yerleri öğretmene } \\
\text { sordum. }\end{array}$ & 2 & 25 \\
\hline & Arkadaşa sorma & Grup arkadaşımla tartıştık. & 1 & 12 \\
\hline & Deneyim kazanma & $\begin{array}{l}\text { Çok fazla özelliği var ama } \\
\text { kullandıkça öğrendim. }\end{array}$ & 2 & 25 \\
\hline $\begin{array}{l}\text { Olumsuz } \\
\text { düşüncem yok }\end{array}$ & $\begin{array}{l}\text { Program hakkında } \\
\text { olumsuz düşüncem }\end{array}$ & $\begin{array}{l}\text { Yok, kullanması kolay ve } \\
\text { eğlenceli }\end{array}$ & 5 & 62 \\
\hline
\end{tabular}

Tablo 4'e göre çğrencilerin \% 62' si olumsuz düşünceye sahip olmadığını belirtmiştir. Öğrencilerin \% 12 si GSP nin bilgisayar gerektirdiğini bu sebeple evde çalışamadıklarını, \% 25' i çok fazla özellik olduğunu ve bunların karışık geldiğini, \% 37 si ise şekil oluştururken zorlandıklarını ifade etmişlerdir. Öğrencilere GSP ile ilgili olumsuzlukları nasıl giderebilecekleri sorulduğunda menüyü kullanamama ve araç oluşturma zorluğunu \%25' i öğretmene sorarak, \% 12' si arkadaşları ile tartışarak ve \% 25 i de deneyim kazanarak aşabileceklerini belirtmişlerdir. Analiz sonuçlarına göre öğrencilerin çok az bir kısmının GSP ile ilgili olumsuz düşünceye sahip olduğu bu düşünceye sebebiyet veren nedenlerin ise öğretmen rehberliği ve program üzerinde çalışma ile ortadan kaldırılabileceği sonucuna ulaşılmıştır.

Tablo 5' te öğrencilerin 'Geleneksel sınıf ortamı ile dinamik geometri ortamını karşılaştırır mısınız?" sorusuna verdikleri cevapların analiz sonuçlarına yer verilmiştir. Öğrenme teması altında öğrencilerin \%50' si dinamik geometri ortamında konuları daha iyi anladığını, \%25, i konuları daha kolay öğrendiğini belirtmişlerdir. Ortam özellikleri teması altında öğrencilerin tamamı dinamik geometri ortamını daha eğlenceli bulduğunu ifade etmiş, eğlenceli bulanların \%75' i programın dinamik olma özelliğinden dolayı eğlenceli bulduklarını, \%25' i de şekil çizerken kağıt kalem kullanmadıkları için GSP kullanmanın zevkli olduğunu belirtmişlerdir.

Tablo 5. Öğrencilerin geleneksel ortam ile dinamik geometri ortamını karşılaştırması.

\begin{tabular}{|c|c|c|c|c|}
\hline & & Öğrenci Görüşleri & $\mathbf{f}$ & $\%$ \\
\hline \multirow{2}{*}{ Öğrenme } & \multirow{2}{*}{ Anlama } & $\begin{array}{l}\text { Dinamik geometri ortamında konuları daha } \\
\text { iyi anladım. }\end{array}$ & 4 & 50 \\
\hline & & Konuları öğrenmesi daha kolay. & 2 & 25 \\
\hline \multirow[t]{2}{*}{$\begin{array}{l}\text { Ortam } \\
\text { Özellikleri }\end{array}$} & \multirow[t]{2}{*}{ Eğlenceli } & $\begin{array}{l}\text { GSP kullanarak öğrenmek daha eğlenceli } \\
\text { çünkü şekillerle oynayabiliyoruz, } \\
\text { istediğimiz gibi } \\
\text { değiştirebiliyoruz, çizerken yaşıyoruz sanki. }\end{array}$ & 6 & 75 \\
\hline & & $\begin{array}{l}\text { Kağıt kalem çok kullanmadık bilgisayarla } \\
\text { uğraşmak daha zevkli }\end{array}$ & 2 & 25 \\
\hline
\end{tabular}


Tablo 5'te hesaplanan verilere göre dinamik geometri ortamının geleneksel ortama göre daha eğlenceli olduğu ve GSP nin kolay ve anlamlı öğrenme sağladığı sonucuna ulaşabiliriz.

Tablo 6`da öğrencilerin “GSP kullanmak derse karşı ilginizi nasıl etkiledi?” sorusuna verdikleri cevapların analizleri gösterilmiştir.

Tablo 6. Öğrencilerin geometri konularına karşı ilgilerinin değişimi.

\begin{tabular}{|c|c|c|c|c|}
\hline & & Öğrenci Görüșleri & $\mathbf{f}$ & $\%$ \\
\hline İlgi & Katılım & $\begin{array}{l}\text { Bu uygulama oldukça eğlenceli bu yüzden } \\
\text { derse olan ilgim arttı. Derse daha çok motive } \\
\text { oluyorum. } \\
\text { Derse istek kazandırdı. Mesela çember çizmeyi } \\
\text { sevmiyordum ama artık seviyorum. }\end{array}$ & 6 & 75 \\
\hline İlgi & Dersi Sevme & $\begin{array}{l}\text { Koordinat sistemi konusunu hiç sevmiyordum } \\
\text { şimdi daha çok seviyorum. } \\
\text { Elle şekil çizmeyi sevmediğim için önceleri } \\
\text { derste sikılıyordum ama şimdi şekil çizmek çok } \\
\text { zevkli bu yüzden geometriyi çok seviyorum } \\
\text { şimdi. }\end{array}$ & 8 & 100 \\
\hline
\end{tabular}

Öğrencilerin \%75' i GSP kullanmak derse yönelik katılımlarını artırdığını, tamamı ise GSP ile yapılan etkinliklerden sonra geometri konularını daha çok sevdiklerini belirtmişlerdir. Tablo 6'daki analiz sonuçları derslerde GSP kullanımı öğrencilerin derse olan ilgilerini ve motivasyonlarını artırdı ğını göstermektedir.

Tablo 7' de öğrencilerin 'Derste Geometer's skatchpad kullanımı geometrik kavramları öğrenmenizi nasıl etkiledi?” sorusuna verdikleri cevapların analizleri yer almıştır.

Tablo 7. Öğrencilerin dinamik geometri ortamında kavram öğrenimi

\begin{tabular}{|c|c|c|c|c|}
\hline & & Öğrenci Görüşleri & $\mathbf{f}$ & $\%$ \\
\hline \multirow{3}{*}{$\begin{array}{l}\text { Kavram } \\
\text { Öğrenme }\end{array}$} & Akılda Kalıcı & $\begin{array}{l}\text { Öğrendiğim kavramları unutmuyorum çünkü } \\
\text { görsel olarak aklımda daha iyi kalıyor. } \\
\text { Kavramlar arasındaki ilişkileri daha iyi anladım } \\
\text { örneğin bir şeklin x eksenine göre yansımasını } \\
\text { gördük koordinatlarının nasıl değiştiğini } \\
\text { öğrendik. Yansımasını gördüğüm için hiç } \\
\text { unutmadım. }\end{array}$ & 4 & 50 \\
\hline & Kolay & Kavramları daha kolay öğrenmemi sağladı. & 6 & 75 \\
\hline & Keşfetme & $\begin{array}{l}\text { Mesela yansıma ile ilgili kuralları etkinliğin } \\
\text { sonunda kendimiz bulduk. Üçgenin alan } \\
\text { formülünü kendimiz çıkardık. }\end{array}$ & 4 & 50 \\
\hline
\end{tabular}


Öğrencilerin \%50' si GSP kullanılarak öğrenilen kavramların daha akılda kalıcı olduğunu, $\%$ 75’ i kavramların daha kolay öğrenildiğini ve \% 50' si kuralları keşfederek öğrendiklerini belirtmişlerdir. Öğrencilerin cevaplarından anlaşılacağı üzere matematik dersinde GSP kullanımı kalıcı ve kolay kavram öğrenimini sağlamaktadır. Öğrencilerin formül ezberlemek yerine akıl yürüterek ve keşfederek bilgiye ulaşmalarına yardımcı olmaktadir.

\section{Tartışma ve Sonuç}

Geometer's Sketchpad dinamik geometri yazılımının ilköğretim matematik sınıflarında kullanılmasıyla ilgili yapılan görüşmelerden elde edilen bulgular incelendiğinde öğrencilerin daha önceki geometri derslerini materyal kullanmadıkları için sıkıcı buldukları ve geometri konularını sevmedikleri sonucu ortaya çıkmıştır. Benzer sonuçlar daha önce yapılan çalışmalarda da ortaya çıkmıştır [10]. Öğrencilerin GSP dinamik yazılımı hakkındaki olumlu görüşleri incelendiğinde öğrencilerin GSP ile geometri öğrenmeyi eğlenceli buldukları, kolay ve doğru şekil çiziminin ve görsel özelliklerinin öğrencilerin motivasyonunu artırdığı sonucuna ulaşılmıştır. Ulaşılan bu sonuç dinamik geometri ortamlarının öğrencilerin derse olan ilgilerini nasıl etkilediğini araştıran çalışmaları destekler niteliktedir. Güven ve Karataş'ın (2003) çalışmalarındaki bulgulara göre öğrenciler dinamik ortamda geometri öğrenmenin 'zevkli', 'eğlenceli', 'renkli', 'bulmaca gibi’ kelimelerle ifade etmişlerdir.

Yapılandırmacı öğrenme kuramına göre öğrenme ezber veya bilgi aktarması yolu ile değil, öğrencinin bilgiyi keşfetmesi, temelden yapılandırması ve zihninde bilgiyle ilgili anlam oluşturması ile sağlanır. Matematik derslerinde GSP kullanımı öğrencilerin kavramlar arasındaki ilişkileri keşfetmelerine ve yeni bilgi oluşturmalarına olanak sağlamaktadır. Öğrencilerin bilgiyi keşfederek yapılandırması öğrenilen geometrik kavramların kalıcılı̆̆ını artırmaktadır.

GSP kullanımı ile ilgili daha önce yapılan araştırmalar öğrenmenin kalıcılığı ile ilgili benzer sonuçlara ulaşılmıştır [5,3]. GSP programının hesap makinesi, araç oluşturma ve koordinat sistemi tanımlama gibi özellikleri zamanın sınıfta etkili kullanımını sağlamaktadır. Bu sonuçlar daha önce konuyla ilgili yapılmış olan araştırma sonuçlarına paralellik göstermektedir [6,17]. Bulguların analizi göstermektedir ki dinamik geometri ortamı ögrencilerin geometri konularına yönelik ilgisini ve derse katılımını artırmaktadır. $\mathrm{Bu}$ sonuç daha önce konuyla ilgili yapılan araştırmaları desteklemektedir. Bintaş ve Bağcıvan'ın (2007) çalışmasındaki anket sonuçlarına göre GSP derse görsellik katarak öğrenmeyi artırıp, zevkli hale getirmiştir [18]. Delice ve Karaaslan (2015) öğrencilerin GeoGebra ve GSP ile konuları daha iyi kavradıkları, dersi eğlenceli buldukları ve derse karşı ilgilerinin arttığını belirtmişlerdir [6].

\section{5. Öneriler}

Çalışmanın sonuçları göz önüne alındığında Türkiye ' de ilköğretim matematik sınıflarında dinamik geometri yazılımlarının kullanılmasının desteklenmesi faydalı olacaktır. Eğitim 
kurumlarının fiziksel donanımı düşünüldüğünde yetkili kurumların eğitim bütçesini planlarken sınıflarda bilgisayar destekli ortamların sağlanmasını gözönünde bulundurmaları uygun bir karar olacaktır. Çalışma sonuçlarına göre GSP programının geometri öğretimine ve öğrenimine sağladığı faydalar düşünülürse bu programı sınıflarda kullanmak öğretmenler için faydalı olacaktır. Bu sebeple öğretmenler derslerde teknolojinin kullanımı ile ilgili bilinçlendirilmeli ve bu programın kullanımı ile ilgili hizmet içi eğitime tabi tutulmalıdır. Yapılan bu çalışma çok kısıtlı öğrenci sayısıyla gerçekleştirildi. Bu konu ile ilgili ilerde araştırma yapacak olan kişiler daha geniş bir örneklemle dinamik geometri yazılımlarının öğrenci başarısına etkisini araştırabilirler.

\section{Kaynaklar}

[1] Güven, B., \& Karataş, İ., Dinamik geometri yazılımı cabrı ile geometri öğrenme: öğrenci görüşleri, The Turkish Online Journal of Educational Technology, 2(2), 67-78, (2003).

[2] Tezci, E., Öğretmenlerin bit entegrasyon yaklaşımlarının ölçülmesine yönelik ölçek geliştirme, Kastamonu Eğitim Dergisi, 24(2), 975-992, (2016).

[3] Güven, B., \& Karataş, İ., Dinamik geometri yazılımı cabri ile oluşturmacı öğrenme ortamı tasarımı: bir model, İlköğretim-Online, 4(1), 62-72, (2005).

[4] Vatansever, S. İlköğretim 7. sınıf geometri konularını dinamik geometri yazılımı geometer's sketchpad ile öğrenmenin başarıya ve kalıcılığa etkisi ve öğrenci görüşleri, Yüksek Lisans Tezi, Dokuz Eylül Üniversitesi, Eğitim Bilimleri Enstitüsü, İzmir, (2007).

[5] Genç, G, \& Öksüz, C., Dinamik matematik yazılımı ile 5. sınıf çokgenler ve dörtgenler konularının öğretilmesi, Kastamonu Eğitim Dergisi, 24(3), 1551-1566, (2015).

[6] Delice, A.\& Karaaslan, G., Dinamik geometri yazılımları ile çokgenler konusunda hazırlanan etkinliklerin öğrenci performansı ve öğretmen görüşlerine yansıması, Karaelmas Eğitim Bilimleri Dergisi. 3, 133-148, (2015).

[7] Kutluca, T., \& Birgin, O., Doğru denklemi konusunda geliştirilen bilgisayar destekli öğretim materyali hakkında matematik öğretmeni adaylarının görüşlerinin değerlendirilmesi, Gazi Ĕgitim Fakültesi Dergisi, 27(2), 81-97, (2007).

[8] Yılmaz, M., Sınıf öğretmeni yetiştirmede teknoloji eğitimi, Gazi Eğitim Fakültesi Dergisi, 27(1), 155-167, (2007).

[9] Steketee, S. (2009). Comparison of Sketchpad And Geogebra. Key Curriculum Press. $\quad$ Retrieved from http://www.keypress.com/documents/GSP5/Detailed_Comparison_of_Sketchpad_a nd_GeoGebra.pdf

[10] Keşan, C., Vatansever, S., \& Kaya, D., Student Opinions about Learning Primary 7th Grade Geometry Subjects with Geometer's Sketchpad. International Online Journal of Educational Sciences, 4(2), 273-282, (2012).

[11] Yıldırım, A. ve Şimşek, H. Sosyal Bilimlerde Nitel Araştırma Yöntemleri, (8.Bask1). Ankara: Seçkin Yayıncılik, (2011).

[12] Zengin, Y., \& Kutluca, T., (September, 2011). Prospectives Mathematics Teachers' Viesw on the Use of Geogebra in Secondary Mathematics Curriculum. 5th 
International Computer \& Instructional Technologies Symposium, Elazı̆̆, Turkey.

[13] Tavşancıl, E. ve Aslan, E. Sözel, Yazılı ve Diğer Materyaller için İçerik Analizi ve Uygulama Örnekleri, Epsilon Yayınevi, İstanbul, (2001).

[14] Bassey, M. Case study research in educational setttigs, Buckingham: Open University Press, (1999),

[15] Şencan, H., Sosyal ve Davranışsal Ölçümlerde Güvenirlik ve Geçerlilik, Ankara: Seçkin Yayıncılık, (2005).

[16] Miles, M, B., \& Huberman, A. M. Qualitative data analysis: An expanded Sourcebook, ( $2^{\text {nd }}$ ed). Thousand Oaks, CA: Sage, (1994).

[17] Hannafin, R. D., Burruss, J. D., \& Little, C., Learning with dynamic geometry programs: perspectives of teachers and learners, The Journal of Educational Research, 94(3), 132-144, (2001).

[18] Bintaş, J., \& Bağcıvan, B., İlköğretim yedinci sınıfta bilgisayar destekli geometri öğretimi, Hasan Ali Yücel Eğilim Fakültesi Dergisi, 1(7), 33-45, (2007).

EK-1

\section{Görüşme Soruları}

Kendinizi tanıtır misınız?

1. Daha önceki matematik derslerinde işlenen geometri konuları ve bu konuların işlenişi hakkında düşünceleriniz nelerdir?

2. Geometer's Sketchpad programı hakkındaki olumlu düşünceleriniz nelerdir?

3. Geometer's Sketchpad programı hakkında olumsuz düşünceleriniz nelerdir?

Aksaklıklar varsa nasıl giderebilirz?

4. Geleneksel sınıf ortamı ile dinamik geometri ortamını karşılaştırır mısınız?

5. Geometer's skatchpad kullanmak derse karşı ilginizi nasıl etkiledi? Örnek verebilir misiniz?

6. Derste Geometer's skatchpad kullanımı geometrik kavramları öğrenmenizi nasıl etkiledi? 